\title{
Primary tumor prevalence has an impact on the constituent ratio of metastases to the jaw but not on metastatic sites
}

\author{
Fu-gui Zhang ${ }^{1}$, Cheng-ge Hua ${ }^{2}$, Mo-lun Shen ${ }^{3}$, Xiu-fa Tang ${ }^{2}$ \\ ${ }^{1}$ State Key Laboratory of Oral Diseases, Sichuan University, Chengdu 610041, China; ${ }^{2}$ Department of Head and \\ Neck Oncology, West China School of Stomatology, Sichuan University, Chengdu 610041, China; ${ }^{3}$ Department of \\ Stomatology, The Second People's Hospital of Hefei, Hefei 230011, China
}

This article provides an overview of metastases to jaws (MJ), mainly concerning the differences between American and Chinese patients, and exploring the relationship between the primary tumors' prevalence (PTP) and constituent ratio of MJ. Information concerning of $399 \mathrm{MJ}$ cases in 215 papers, including one new case in our hospital, was subjected to statistic analysis. The main clinical features of $\mathrm{MJ}$, such as constituent ratio of PTP and that of MJ, metastatic sites, treatments, and prognosis were summarized. Breast, lung, kidney, prostate and thyroid (in descending order) were the leading primary sites of MJ. Furthermore, the constituent ratio of MJ was found to be correlated with that of PTP in all subjects including American and Chinese subjects in our study. As to metastatic sites in the mandible, a specific " $M$ " shaped pattern appeared regardless of the tumor type or constituent ratios of $\mathrm{MJ}$ were in all subjects. Almost all subjects received traditionally palliative treatments, and the prognosis was quite poor. The PTP had a significant impact on the constituent ratio of MJ. However, it was the properties of the microenvironment rather than characteristics or constituent ratios of tumor cells, that decided the metastatic sites in various tumor subjects.

Keywords: tumor; metastases; jaws

International Journal of Oral Science (2011) 3: 141-152. doi: 10.4248/IJOS 11052

\section{Introduction}

Metastatic tumors from distant primary foci to the oral and maxillofacial (OMF) region are rare, accounting for only $1 \%$ of all malignancies in the OMF region. The jaw bones, especially the mandible, are the most frequently involved colonizing sites [1-3]. Though most metastases to the OMF region (OMF metastases) are noted after the diagnosis and treatment of the primary malignancy else-

*Correspondence: Cheng-ge Hua

Tel: 8602885501428 ; Fax: 8602885501445

E-mail: huacg@163.com

Received 30 July 2010; Accepted 5 June 2011 where, about one-third of them are the initial sign of a cancer. The diagnosis usually involves searching for the primary disease, and the follow-up treatment is quite a challenge, often with unsatisfactory curative results to OMF surgeons and related clinicians [4-5].

Although a few anatomic routines were suspected as the metastatic pathways [6-7], the precise mechanism of OMF metastasis is still unclear.

In one of our previous papers [8], the incidence of OMF metastases was found to be influenced by the PTP. However, there was no linear correlation between the two. Theoretically, the lack of a relationship could be due to the interaction between the unequal metastasizing opportunity of different tumors and the diverse microen- 
vironment in different tissues. The similar tissue environment of jaw bones provides an opportunity for further study to exclude the influence of different host environment on the progress of the metastases.

Based on the above presumptions, we conducted a systematic analysis of $387 \mathrm{MJ}$ reported in the literatures together with 12 cases in our hospital, then assessed the relationship between the PTP and constituent ratio of MJ.

\section{Patients and Methods}

\section{Case report}

This study was ratified by the Committee for the Use of Human Subjects in Research, Sichuan University. One new case added was a mandible metastasis from the left lung of a 78-year-old man who initially complained of numbness of the lower lip, and was then referred to our hospital in July 2008. A chest CT scan showed an irregular soft tissue mass in the left lung and a panographic X-ray showed pathological fracture in his left mandible. Biopsy of both foci demonstrated adenocarcinoma from the lung (Figure 1). Treatment was declined by the patient, and follow-up was available only for one month.

\section{Search strategy}

We systematically searched MEDLINE (Medical Literature Analysis and Retrieval System online) and CBMdisc (China BioMedical literature on disc) for English and Chinese papers (January 1950-August 2008) by entering 'jaw neoplasms'/sc (secondary) and 'maxillary sinus neoplasms'/sc as the medical subject heading terms, together with "metastasis" or "metastases" or "metastasize" or "metastasizing", with "maxilla", "maxillary", "maxillary sinus", "maxillary antrum", "mandible", "mandibular", "condyl*", "ramus", "jaw*", or "jaw bone", and with "mouth", "oral", "oral cavity", "maxillofacial", "craniofacial" or "head and neck region" as the text words. A total of 411 papers were retrieved and checked carefully, and their reference lists were explored to find other potentially relevant papers. Furthermore, 9427 cases of hospitalized patients with OMF malignancies treated in the West China Hospital of Stomatology, from January 1954 to August 2008, were analyzed to find cases of MJ. Clausen-Meyer criteria were employed as inclusion criteria [9-10], as follows: 1) a proved primary tumor with histologic confirmation and possible roentgenographic supportive evidence; 2) maxillary and mandibular metastasis with histologic confirmation and possible roentgenographic evidence; 3)
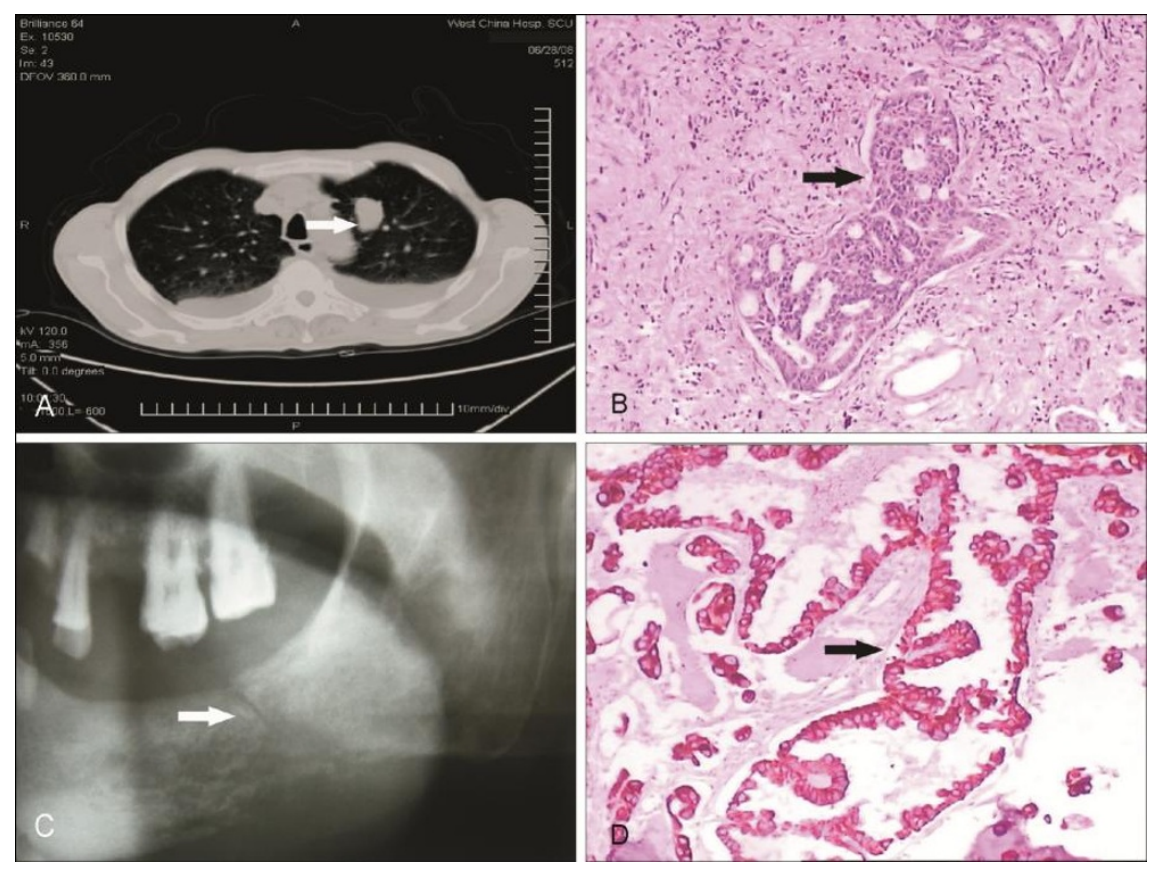

Figure $1 \mathrm{~A}$ rare case of $\mathrm{MJ}$ encountered in West China Hospital of Stomatology, who was admitted because of numbness of the lower lip and pathological fracture. (A) A chest CT scan shows an irregular soft tissue mass in the left lung and pleural fluid in both lungs. (B) A transthoracic needle aspiration biopsy identifies a mediate differentiated adenocarcinoma. HE stain, $\times 200$. (C) The arrowhead points to the fracture site of left mandible. (D) Biopsy of the mandible demonstrates adenocarcinoma from lung. LCK stain, $\times 200$. 
histologic correlation of the metastatic jaws lesion with primary lesion; and, 4) when the primary lesion is anatomically near the metastasis, there should no tumor tissue be present between the two foci. Reports were excluded that had no clinical, radiographic and histologic evidences to confirm the diagnosis as primary sites. The main clinical features, such as constituent ratio of PTP and that of MJ, metastatic sites, treatment and prognosis were summarized. The five-year prevalence data of primary foci were obtained from GLOBOCAN 2002 [11]. And the International Classification of Diseases Edition 10 (ICD-10) is adopted in this article.

\section{Data analysis}

Rank correlation, Chi-square test and Kruskal-Wallis Test were used to compare the different characteristics of MJ. Survival analysis was also used to analyze the outcome and survival time. Data are expressed as mean \pm SEM. A probability of 0.05 or less was considered significant.

\section{Results}

\section{General information}

A total of 214 papers containing 387 searched MJ patients were analyzed [1-7, 9-10, 12-216]. In addition, twelve cases of $\mathrm{MJ}$ in our hospital were assessed including 11 reported cases [8] and one newly-reported case. Among 215 papers and 399 patients, 92 papers from the English-language literature, with $143 \mathrm{MJ}$ cases, while 37 papers were associated with 91 Chinese MJ patients. Genders was noted for 212 male patients and 179 female patients. The age of the 365 published cases ranged from 9 months to 90 years, with a mean of $51.48 \pm$ 1.03 .

Constituent ratio of $M J$ (proportion of different primary sites within MJ)

The most common primary foci of MJ (classified by ICD-10), were breast, followed in descending order by lung, kidney, liver and intrahepatic bile duct (liver \& IBD), prostate and thyroid, taking up $19.30 \%, 13.03 \%$, $11.28 \%, 8.52 \%, 8.02 \%$ and $8.02 \%$, respectively (Table 1). The most common primary sites in China were liver and intrahepatic bile duct (liver \& IBD, 18.68\%) and lung $(18.68 \%)$, followed by thyroid $(14.29 \%)$, breast $(12.09 \%)$, and kidney $(7.69 \%)$, while the most popular primary foci in the USA were breast $(24.48 \%)$, prior to kidney $(13.29 \%)$, lung $(11.19 \%)$, prostate $(9.09 \%)$, and intestine $(6.29 \%)$. We found there was a significant difference in constituent ratio of MJ between the USA and China by Chi-square test $(P<0.01$, Figure 2$)$.

\section{Correlation between constituent ratio of PTP and that of MJ}

The five-year prevalence data of primary tumors were converted into constituent ratios of PTP (Table 1), and a rank correlation test was performed between the cons-

Table 1 The constituent ratio comparison between 5-year prevalence and no. of MJ of primary sites

\begin{tabular}{|c|c|c|c|c|c|}
\hline \multirow{2}{*}{ Primary sites } & \multicolumn{2}{|r|}{ MJ } & \multicolumn{2}{|c|}{ 5-year Prevalence } & \multirow[t]{2}{*}{ ICD-10 } \\
\hline & Cases & Constituent ratio $/ \%$ & Cases & Constituent ratio $/ \%$ & \\
\hline Oesophagus & 12 & 3.01 & 424470 & 1.73 & $\mathrm{C} 15$ \\
\hline Stomach & 11 & 2.76 & 1473559 & 6.00 & $\mathrm{C} 16$ \\
\hline Colon and rectum & 23 & 5.76 & 2830416 & 11.52 & $\mathrm{C} 17-20$ \\
\hline Liver \& IBD & 34 & 8.52 & 385985 & 1.57 & $\mathrm{C} 22$ \\
\hline Pancreas & 4 & 1.00 & 142837 & 0.58 & $\mathrm{C} 25$ \\
\hline Lung & 52 & 13.03 & 1362226 & 5.54 & C33-34 \\
\hline Melanoma of skin & 5 & 1.25 & 642643 & 2.62 & $\mathrm{C} 43$ \\
\hline Breast & 77 & 19.30 & 4406080 & 17.93 & $\mathrm{C} 50$ \\
\hline Uterus & 13 & 3.26 & 2184807 & 8.89 & C53-54 \\
\hline Prostate & 32 & 8.02 & 2368659 & 9.64 & C61 \\
\hline Testis & 4 & 1.00 & 192239 & 0.78 & C62 \\
\hline Kidney etc. & 45 & 11.28 & 585639 & 2.38 & C64-65 \\
\hline Bladder & 7 & 1.75 & 1110265 & 4.52 & C66-67 \\
\hline Brain, nervous system & 4 & 1.00 & 276546 & 1.13 & C70-72 \\
\hline Thyroid & 32 & 8.02 & 531369 & 2.16 & $\mathrm{C} 73$ \\
\hline Others & 44 & 11.03 & 5652375 & 23.01 & \\
\hline All sites but skin & 399 & 100.00 & 24570115 & 100.00 & \\
\hline
\end{tabular}


tituent ratio of PTP and that of MJ. Interestingly, there was a significant linear correlation between them (Spearman' correlation coefficient $=0.621, P=0.010$ ). For example, carcinomas of breast, lung and prostate had a high incidence of MJ in our study. Thus, they had likewise a high prevalence in the GLOBOCAN 2002. It is interesting to note that there also exists a linear correlation between them in the USA (correlation coefficient $=0.567$, $P=0.027$ ), as well as in China (correlation coefficient= $0.523, P=0.046$, Figure 2).

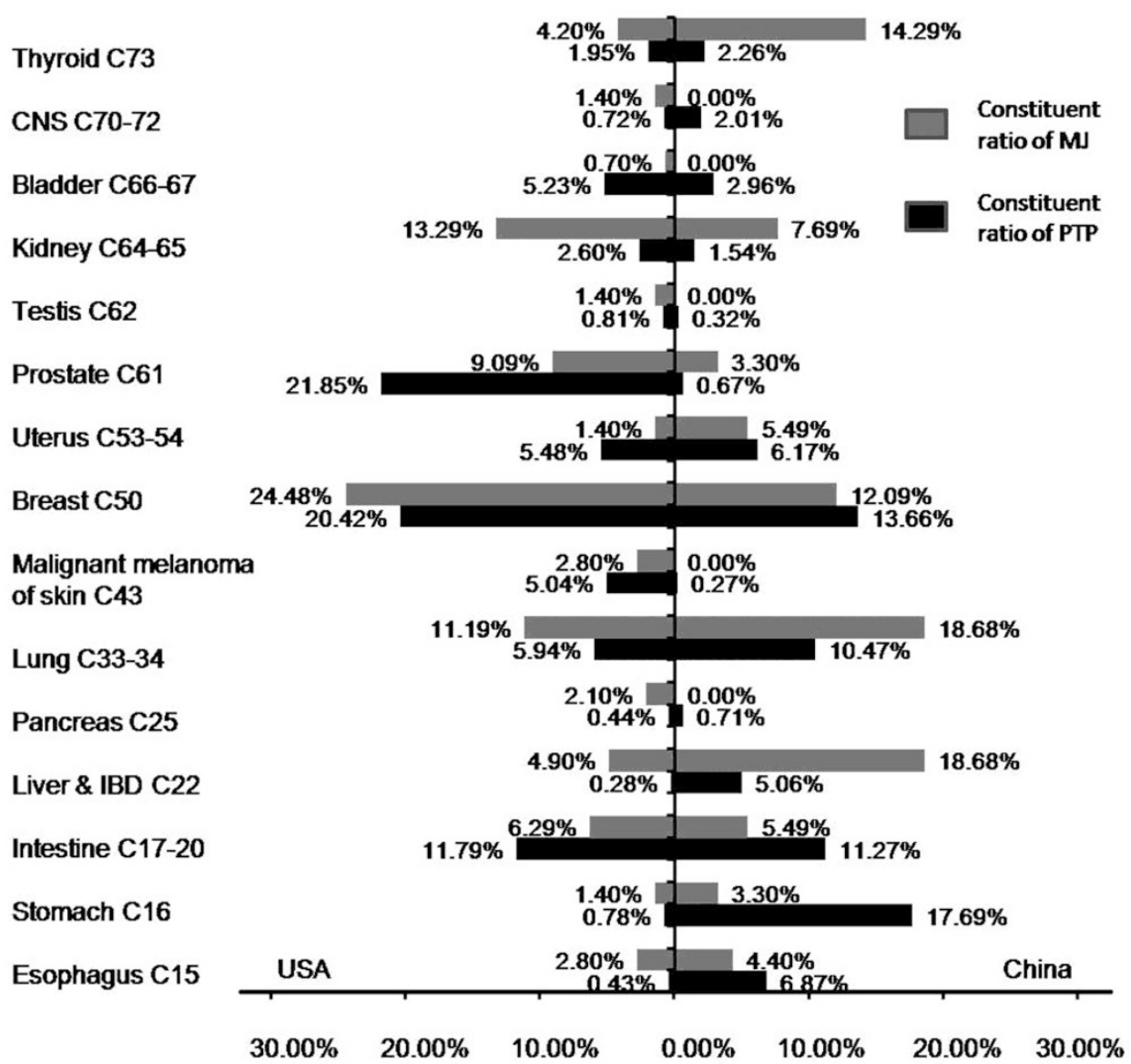

Figure 2 The major constituent ratio of PTP in all cancers (not including non-melanoma skin cancers) and their constituent ratio in MJ.

\section{Metastatic sites}

Most MJ involved one oral site (383 cases), and only a few involved two or three sites (14 cases and 2 cases, respectively). Among them, eight metastases invaded both jaw bones. The mandible was more commonly involved than maxilla (337 cases: 70 cases). Most tumors metastasized to the unilateral mandible, whereas only three cases to bilateral mandibles. A total of $337 \mathrm{MJ}$ cases involved 474 specific sites of the mandible including 111 undefined sites (i.e., 72 cases of "mandible" and 39 cases of "body"). Interestingly, these sites were distributed in an "M" curve pattern, with ramus (92 sites) and molar area (91 sites) the most frequently encountered specific sites, followed by angle ( 57 sites), premolar area (48 sites), condyle (43 sites), and anterior area (28 sites, Figure 3).

It was also found that each primary tumor metastasized to specific sites of the same pattern, i.e., there were no significant statistical differences between primary tumors and specific sites $(P>0.05)$. It is interesting that the "M" curves existed for all cases we studied and the same was true for both American and Chinese cases. There was no significant differences in specific metastatic sites between the American and Chinese cases by Chisquare test $(P>0.05)$. 


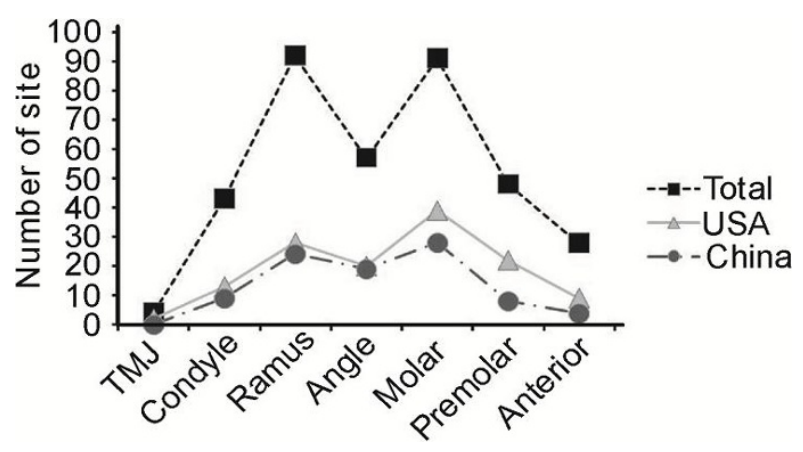

Figure 3 An interesting universal "M" curve with ramus and molar area standing out as peak point of metastatic sites.

\section{Treatments and prognosis}

Treatment and prognosis were documented in 230 cases. Among them, radiotherapy was the most commonly adopted monotherapy (115 cases), followed by chemotherapy (93 cases), surgery ( 87 cases), symptomatic treatment ( 5 cases), embolization ( 3 cases) and supportive care $(2$ cases). A total of 72 subjects accepted two or three of the above mentioned therapies (i.e., multitherapy). The mean survival times of surgical, radiotherapeutic and chemotherapeutic subjects were $15.84 \pm 4.46$, $6.24 \pm 1.27$, and $7.30 \pm 1.87$ months, respectively. And the mean survival times of non-therapeutic, multitherapeutic, and mono-therapeutic groups were $9.11 \pm 2.25$, $11.79 \pm 2.23$, and $9.51 \pm 1.61$ months, respectively. However, there were no significant differences among them by Kruskal-Wallis Test $(P>0.05)$. The mean survival time of all subjects was $9.90 \pm 1.14$ month. Fifty percent of cases died $5.30 \pm 0.39$ months after diagnosis of $\mathrm{MJ}$; $75 \%$ cases died in $13.97 \pm 2.17$ months, and the fiveyear survival rate was only $2.58 \%$ (Figure 4 ).

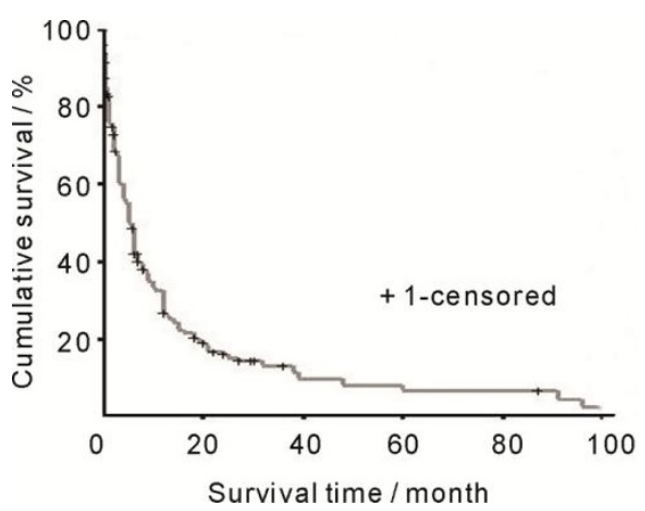

Figure 4 Survival curve of MJ patients.

\section{Discussions}

The authors conducted a systematic analysis of 399 cases and evaluated the relationship between the PTP and constituent ratio of MJ. The most common primary foci of $\mathrm{MJ}$ were breast, followed by lung, kidney, prostate and thyroid. Interestingly, there was a significant linear correlation between the constituent ratio of PTP and that of MJ. The metastatic sites were distributed specifically in an " $M$ " curve pattern, and the prognosis of these patients was quite poor when treated by a traditional "seeds-oriented" therapeutic strategy.

From the perspective of anatomy, bone and soft tissues of the OMF region share a common blood-supply, but provide absolutely different tissue environments. A valid premise may be that metastatic tumor cells select a favorable environment to anchor and proliferate, this being the tissue/organ specificity of cancer metastasis [217]. And the "seed-soil" theory proposed by Paget is accepted as the basic mechanism for cancer metastasis [218-220]. The results of these studies have enriched the Paget's hypothesis: the potential of a tumor cell to metastasize depends on its interactions with the homeostatic factors that promote tumor cell growth, survival, angiogenesis, invasion and metastasis [221].

According to the results of rank correlation analysis in our previous work, there was no significant linear relationship between the constituent ratio of PTP and that of OMF metastases [8]. However, when it was narrowed down to $\mathrm{MJ}$, a linear relationship was established between constituent ratio of PTP and that of MJ. The results suggest that different tissue environments could cause bias in the relationship between PTP and constituent ratio of $\mathrm{MJ}$.

With respect to favorable metastatic sites of $\mathrm{MJ}$, it was interesting to see the appearance of an " $\mathrm{M}$ " curve in all cases including American and Chinese cases. Successful metastatic cells depend largely on the virtue of intrinsic features of the cells and the ability of the tumor cells to engage and interact successfully with the microenvironment [222]. However, according to our result, there was no significant difference between primary tumors and specific sites $(P>0.05)$. Thus, it seems that regardless of tumor type or constituent ratios of $\mathrm{MJ}$, metastases formed preferentially in the mandible. In other words, the characteristics of the microenvironment rather than properties or constituent ratios of tumor cells decided the metastatic site.

According to our study results, the prognosis of $\mathrm{MJ}$ was not different among non-therapeutic, multitherapeutic, and monotherapeutic groups, which reflects the shortcomings of the current "seeds-oriented" therapeutic 
strategy. Perhaps, reformation of the "soil" might inhibit the formation and development of the metastases, if the growth and dissemination of the primary tumors cells (i.e., "seeds") can be impeded. In the past decades, this strategy was experimented in several new anti-cancer therapeutic regimens, such as anti-tumor angiogenesis, organ growth factors, etc., one of which got dramatic effect in treating metastases: the clinic use of bisphosphonates to inhibit bone metastases by changing bone metabolism. Bisphosphonates are potent inhibitors of bone osteolysis and could interrupt the tumor cell adhering to bone marrow, thereby impeding both the development of bone metastases and preventing the tumor cells and dormant cells in the bone marrow microenvironment from subsequent dissemination to extra-osseus sites [223-224]. Furthermore, it could be better still if we could find methods to change the metabolism of soft tissues.

\section{Conclusion}

The PTP had a significant impact on constituent ratio of MJ. Our findings may have significant value for clinicians to evaluate the risks of $\mathrm{MJ}$ occurrence in various tumor patients. However, it was the properties of microenvironment rather than properties or constituent ratios of tumor cells that decided the metastatic sites. Therefore, interference with the "microenvironment" may be was an efficient therapeutic strategy for inhibiting metastatic tumor growth in jawbones.

\section{References}

1 Linkous CM, Welch JT. Metastatic malignant tumors of the jaws: report of a case. Oral Surg 1974; 38: 703-707.

2 Gerlach KL, Horch HH, Feaux de Lacroix W. Condylar metastasis from bronchial carcinoma. Case report. J Maxillofac Surg 1982; 10: 250-252.

3 Yagan R, Bellon EM, Radivoyevitch M. Breast carcinoma metastatic to the mandible mimicking ameloblastoma. Oral Surg Oral Med Oral Pathol 1984; 57: 189-194.

4 Pruckmayer M, Glaser C, Marosi C, Leitha T. Mandibular pain as the leading clinical symptom for metastatic disease: Nine cases and review of the literature. Ann Onco 1998; 9: 559-564.

5 van der Waal RI, Buter J, van der Waal I. Oral metastases: report of 24 cases. Br J Oral Maxillofac Surg 2003; 41: 3-6.

6 Milobsky SA, Milobsky L, Epstein LI. Metastatic renal adenocarcinoma presenting as periapical pathosis in the maxilla. Oral Surg Oral Med Oral Pathol 1975; 39: 30-33.

7 Shankar S. Dental pulp metastases and pan-osseous mandibular involvement with mammary adenocarcinoma.
Br J Oral Maxillofac Surg 1984; 22: 455-461.

8 Shen ML, Kang J, Wen YL, et al. Metastatic tumors to the oral and maxillofacial region: a retrospective study of 19 cases in west China and review of the Chinese and English literature. J Oral Maxillofac Surg 2009; 67: 718-737.

9 Clausen F, Poulsen H. Metastatic carcinoma to the jaws. Acta Pathol Microbiol Scand 1963; 57: 361-374.

10 Meyer I, Shklar G. Malignant tumors metastatic to mouth and jaws. Oral Surg Oral Med Oral Pathol 1965; 20: 350362.

11 Ferlay J, Bray F, Pisani P. GLOBOCAN 2002: cancer incidence, mortality and prevalence worldwide. IARC. Cancer Base. 5th edition. Lyon: IARC Press, 2004.

12 Adler CI, Sotereanos GC, Valdivieso JG. Metastatic bronchogenic carcinoma to the maxilla: report of case. J Oral Surg 1973; 31: 543-546.

13 Aisenberg MS, Gardner AF, Inman CL Sr. Osteoma of the mandible. Oral Surg Oral Med Oral Pathol 1960; 13: 13561359.

14 Al-Ani S. Metastatic tumors to the mouth: report of two cases. J Oral Surg 1973; 31: 120-122.

15 Anderson RS, Peeples WJ. Mandibular osseous metastasis from esophageal carcinoma: a case report and review of the literature. J Oral Maxillofac Surg 1990; 48: 188-192.

16 Angelopoulos AP, Tilsn HB, Stewart FW. Metastatic neuroblastoma of the mandible: review of literature and report of case. J Oral Surg 1972; 30: 93-106.

17 Anil S, Lal PM, Gill DS, Beena VT. Metastasis of thyroid carcinoma to the mandible. Case report. Aust Dent J 1999; 44: 56-57.

18 Appenzeller J, Weitzner S, Long GW. Hepatocellular carcinoma metastatic to the mandible: report of case and review of literature. J Oral Surg 1971; 29: 668-671.

19 Ashworth DR, Whear NM. Enophthalmos caused by metastatic breast carcinoma. Br J Oral Maxillofac Surg 2002; 40: 350-351.

20 Banerjee SC. Metastasis to the mandible. Oral Surg Oral Med Oral Pathol 1967; 23: 71-77.

21 Barrera-Franco JL, Flores-Flores G, Mosqueda-Taylor A. Mandibular metastasis as the first manifestation of hepatocellular carcinoma: report of a case and review of the literature. J Oral Maxillofac Surg 1993; 51: 318-321.

22 Bastian HL, Jensen EK, Jylling AM. Urachal carcinoma with metastasis to the maxilla: the first reported case. J Oral Pathol Med 2001; 30: 378-380.

23 Bergstedt HF, Haverling M. Facial bone scintigraphy. I . Metastatic lesions in the mandible. Acta Radiol Diagn (Stockh) 1978; 19: 859-864.

24 Bernstein JM, Montgomery WW, Balogh K Jr. Metastatic tumors to the maxilla, nose, and paranasal sinuses. Laryngoscope 1966; 76: 621-650.

25 Bhattacharyya I, Williamson A, Cohen DM, Bever JL. 
Metastatic neuroblastoma with ganglioneuromatous differentiation and mandibular involvement. Oral Surg Oral Med Oral Pathol 1999; 88: 586-592.

26 Birkholz H. Metastatic bronchogenic carcinoma to the maxilla. J Oral Maxillofac Surg 1982; 40: 532-534.

27 Block RM, Mark HI, Bushell A. Metastatic carcinoma of the breast mimicking periapical disease in the mandible. $J$ Endod 1977; 3: 197-199

28 Bodner L, Sion-Vardy N, Geffen DB, Nash M. Metastatic tumors to the jaws: a report of eight new cases. Med Oral Patol Oral Cir Bucal 2006; 11: E132-E135.

$29 \mathrm{Bu}$ FJ. Renal cell carcinoma metastatic to the maxillary sinus. Zhongguo Zhong Liu Lin Chuang 1982; 9: 208.

30 Bucin E, Andrasson L, Bjorlin G. Metastases in the oral cavity. Case report. Int J Oral Surg 1982; 11: 321-325.

31 Carl W. Tumor metastases to the oral cavity. Quintess Int Dent Dig 1980; 11:11-16.

32 Carroll MK, Krolls SO, Mosca NG. Metastatic carcinoma to the mandible. Report of two cases. Oral Surg Oral Med Oral Pathol 1993; 76: 368-374.

33 Carter DG, Anderson EE, Currie P. Renal cell carcinoma metastatic to the mandible. J Oral Surg 1977; 35: 992-993.

34 Cash CD, Royer RQ, Dahlin DC. Metastatic tumors of the jaws. Oral Surg Oral Med Oral Pathol 1961; 14: 897-905.

35 Cataldo E, Savage M, Shklar RG. Osteogenic sarcoma of femur metastatic to mandible. Report of a case. Oral Surg Oral Med Oral Pathol 1965; 19: 86-92.

36 Catone GA, Henny FA. Metastatic gastric adenocarcinoma of the mandible: report of a case. J Oral Surg 1969; 27: 36-40.

37 Catrambone RJ, Pfeffer RC. Significant postoperative hemorrhage following biopsy of a prostate tumor metastatic to the mandibular condyle: report of a case. J Oral Maxillofac Surg 1990; 48: 858-861.

38 Chen BZ, Yang W, Xue NH. Metastatic tumors to the jawbones: report of 4 cases. Xian Dai Zhong Xi Yi Jie He Za Zhi 1998; 7: 594.

39 Chen SY, Cheng PW, Tsai CC. Pathology quiz case. Mandibular metastasis of hepatocellular carcinoma. Arch Otolaryngol Head Neck Surg 2005; 131: 735-736.

40 Cherry CQ, Glass RT. Large-cell carcinoma metastatic to the jaw. Report of a case. Oral Surg Oral Med Oral Pathol 1977; 44: 358-361.

41 Chin A, Liang TS, Borislow AJ. Initial presentation of hepatocellular carcinoma as a mandibular mass: case report and review of the literature. Oral Surg Oral Med Oral Pathol Oral Radiol Endod 1998; 86: 457-460.

42 Choukas C, Toto PD, Choukas NC. Metastatic breast carcinoma mandible in gynecomastia gynecomastic. Case report. Oral Surg Oral Med Oral Pathol 1993; 76: 757-759.

43 Ciebien M, Belting CM. Mucoepidermoid tumor metastatic to the mandible: case report. Mil Med 1975; 140: 32-35.
44 Cinberg JZ, Terrife D. Follicular adenocarcinoma of the thyroid in the maxillary sinus. Otolaryngol Head Neck Surg 1980; 88: 157-158.

45 Ciola B, Yesner R. Radiographic manifestations of a lung carcinoma with metastases to the anterior maxilla. Oral Surg Oral Med Oral Pathol 1977; 44: 811-816.

46 Cohen DM, Green JG, Diekmann SL, Howell RM, Harn SD. Maxillary metastasis of transitional cell carcinoma: report of a case. Oral Surg Oral Med Oral Pathol 1989; 67: 185-189.

47 Cooney BM, Ruth GJ, Behrman DA, Bova GS, Behrman SJ. Malignant cystosarcoma phyllodes of the breast metastatic to the oral cavity: report of a case and review of the literature. Oral Surg Oral Med Oral Pathol 1988; 66: 599 604.

48 Cousin GC, Ilankovan V. Mental nerve anaesthesia as a result of mandibular metastases of prostatic adenocarcinoma. Br Dent J 1994; 177: 382-384.

49 Cranin AN, Berman S, Tucker N. Renal-cell carcinoma of the mandibular periodontium. Oral Surg Oral Med Oral Pathol 1966; 21: 626-631.

50 Curtin J, Radden BG. Mandibular metastasis from a primary adenocarcinoma of the fallopian tube. J Oral Maxillofac Surg 1985; 43: 636-638.

51 Dai JH, Li MS, Zeng YL, Wang J. The clinical radiological findings of metastatic tumor of the jaw bone (report of 5 cases). J Chin Clin Med Imaging 2005; 16:354-355.

52 de Courten A, Irle C, Samson J, Lombardi T. Metastatic transitional cell carcinoma of the urinary bladder presenting as a mandibular gingival swelling. $J$ Periodontol 2001; 72 : 688-690.

53 de Padua Bertelli A, Queiroz Costa F, Miziara JE. Metastatic tumors of the mandible. Oral Surg Oral Med Oral Pathol 1970; 30: 21-28.

54 DeBoom GW, Jensen JL, Siegel W, Bloom C. Metastatic tumors of the mandibular condyle. Review of the literature and report of a case. Oral Surg Oral Med Oral Pathol 1985; 60: $512-516$.

55 Delfino JJ, Wilson TK, Rainero DM. Metastatic adenocarcinoma from the colon to the mandible. J Oral Maxillofac Surg 1982; 40: 188-190.

56 Deng TC, Zhang MX. Rectal adenocarcinoma metastatic to the mandible and gingiva: A case report. Zhonghua Zhong Liu Za Zhi 1992; 14: 442.

57 Deutsch M, Wollman MR. Radiotherapy for metastases to the mandible in children. J Oral Maxillofac Surg 2002; 60: 269-271.

58 Deutsch M, Ellerbroek NA, Rosenstein M. Radiotherapy for symptomatic metastases to the mandible in adults. Am J Clin Onco 2003; 26: 252-253.

59 Donoff RB, Albert T, Olson DJ, Guralnick W. Metastatic bronchogenic carcinoma to the mandible. J Oral Surg 1976; 34: 1007-1011. 
60 Dosoretz DE, Orr JW Jr, Salenius SA, Orr PF. Mandibular metastasis in a patient with endometrial Cancer. Gynecol Onco 1999; 72: 243-245.

61 Doval DC, Kannan V, Kumaraswamy SV, et al. Mandibular metastasis in hepatocellular carcinoma. Int J Oral Maxillofac Surg 1992; 21: 97-98.

62 Doykos JD 3rd. Wilms tumor metastatic to mandible and oral mucosa. Report of a case. Oral Surg Oral Med Oral Pathol 1969; 27: 220-224.

63 Doyle JL, Goldman HM. Primary osteogenic sarcoma and metastatic renal-cell carcinoma of the mandible. Case reports and necropsy findings. Oral Surg Oral Med Oral Pathol 1966; 21 : 419-430.

64 Draper BW, Precious DS, Priddy RW, Byrd DL. Clinicohistological conference. Case 29, part 2. Follicular thyroid carcinoma metastatic to the mandible. J Oral Surg 1979; 37: 736-739.

65 D'Silva NJ, Summerlin DJ, Cordell KG, et al. Metastatic tumors in the jaws: A retrospective study of 114 cases. $J \mathrm{Am}$ Dent Assoc 2006; 137: 1667-1672.

66 Ehlinger P, Peeters LC, Servais J, Fossion E. Hormonal therapy in the treatment of mandibular metastasis of breast carcinoma. Report of a case. Int J Oral Maxillofac Surg 1993; 22: 108-109.

67 Englert TP, Kahn MR, Bushkoff SH, Mendelow $\mathrm{H}$. Mandibular metastasis of an extraskeletal myxoid chondrosarcoma arising on the plantar surface of the foot: report of case. J Oral Surg 1978; 36: 401-405.

68 Epker BN, Merrill RG, Henny FA. Breast adenocarcinoma metastatic to the mandible. Report of seven cases. Oral Surg Oral Med Oral Pathol 1969; 28: 471-479.

69 Fan JB, Bian SZ. Follicular thyroid carcinoma metastatic to the mandible: A case report. Xian Dai Kou Qiang Yi Xue Za Zhi 1995; 9:168.

70 Fay JT, Weir GT. Metastatic renal cell carcinoma from a primary tumor removed 14 years previously. J Oral Maxillofac Surg 1983; 41: 129-132.

71 Florine BL, Simonton SC, Sane SM, et al. Clear cell sarcoma of the kidney: report of a case with mandibular metastasis simulating a benign myxomatous tumor. Oral Surg Oral Med Oral Pathol 1988; 65: 567-574.

72 Freilich RE. Adenocarcinoma of the pancreas metastatic to the mandible. J Oral Maxillofac Surg 1986; 44: 735-737.

73 Fukuda M, Miyata M, Okabe K, Sakashita H. A case series of 9 tumors metastatic to the oral and maxillofacial region. $J$ Oral Maxillofac Surg 2002; 60: 942-944.

74 Fung EH. Metastatic adenocarcinoma of the mandible from the rectum. Aust Dent J 1981; 26: 101-104.

75 Giles DL, McDonald PJ. Pathologic fracture of mandibular condyle due to carcinoma of the rectum. Oral Surg Oral Med Oral Pathol 1982; 53: 247-249.

76 Gorsky M, Silverman S Jr, Greenspan D, Deluchi S, Merrell
P. Metastatic chordoma to the mandible. Oral Surg Oral Med Oral Pathol 1983; 55: 601-604.

77 Goveia G, Bahn S. Asymptomatic hepatocellular carcinoma metastatic to the mandible. Report of a case. Oral Surg Oral Med Oral Pathol 1978; 45: 424-430.

78 Haggerty DR. Case for diagnosis. Bronchial carcinoid, metastatic to the mandible. Mil Med 1987; 152: 161-162.

79 Hagglund G. Adenocarcinoma of the mandible: a metastasis from a primary tumor in the sigmoid colon. Report of a case. Oral Surg Oral Med Oral Pathol 1959; 12: 1228-1234.

80 Hardt NP. Metastatic neuroblastoma in the mandible. Report of a case. Oral Surg Oral Med Oral Pathol 1976; 41: 314 320 .

81 Hashimoto N, Kurihara K, Yamasaki H, Ohba S, Sakai H, et al. Pathological characteristics of metastatic carcinoma in the human mandible. J Oral Pathol 1987; 16: 362-367.

82 Hayes RL, Pinson TJ, Leffall LD. Adenocarcinoma of the pancreas metastatic to the mandible. Oral Surg Oral Med Oral Pathol 1966; 21: 61-66.

83 Hefer T, Manor R, Zvi Joachims H, et al. Metastatic follicular thyroid carcinoma to the maxilla. J Laryngol Otol 1998; 112: 69-72.

84 Hertz RS, Cesario WH. Metastatic carcinoma of the mandible secondary to adenocarcinoma of the lung. Report of a case. Oral Surg Oral Med Oral Pathol 1962; 15: 658-664.

85 Hoffken H, Rummel HH, Schulz P, Tschahargane C. Cytology of a mammary carcinoma metastasis at the angle of the mandible: a case report. Acta Cytol 1982; 26: 705708 .

86 Hoffman S, Green GH. Neuroblastoma with metastasis to the mandible: report of case. J Oral Surg 1966; 24: 75-81.

87 Hua CG, Wen YM. Metastases to oral and maxillofacial region. J Modern Stomatol 2001; 15: 345-346

88 Johal AS, Davies SJ, Franklin CD. Condylar metastasis: a review and case report. Br J Oral Maxillofac Surg 1994; 32: 180-182.

89 Jones GM, Telfer MR, Eveson JW. Metastatic renal clear cell carcinoma of the jaws. Two cases illustrating clinical and histological diagnostic problems. Br J Oral Maxillofac Surg 1990; 28: 172-175.

90 Junquera L, Rodriguez-Recio C, Torre A, Sánchez-mayoral J, Fresno MF. Hepatocellular carcinoma metastatic to the mandible: a case involving severe hemorrhage. Med Oral 2004; 9: 345-349.

91 Kahn MA, McCord PT. Metastatic thyroid carcinoma of the mandible: case report. J Oral Maxillofac Surg 1989; 47: 1314-1316.

92 Karr RA, Best CG, Salem PA, Toth BB. Synovial sarcoma metastatic to the mandible: report of two cases. J Oral Maxillofac Surg 1991; 49: 1341-1316.

93 Kaugars GE, Svirsky JA. Lung malignancies metastatic to the oral cavity. Oral Surg Oral Med Oral Pathol 1981; 51 
179-186.

94 Kerpel SM, Freedman PD. Metastatic mesothelioma of the oral cavity. Report of two cases. Oral Surg Oral Med Oral Pathol 1993; 76: 746-751.

95 Koyama T, Hashimoto K, Yamaguchi K, Fukuda H. Esophageal carcinoma metastatic centrally to the mandible: a case report with implication of cell proliferating marker Ki-67. J Oral Maxillofac Surg 1997; 55: 640-645.

96 Kranz WC Seminoma metastatic to the maxilla. Report of a case. Oral Surg Oral Med Oral Pathol 1966; 21: 196-200.

97 Kreutz RW, Christensen RE Jr, Fish LR. Glomangiosarcoma with metastasis to the maxilla. Int J Oral Maxillofac Surg 1987; 16: 116-118.

98 Lai QS, Liu JC. Malignant tumors metastatic to the mandible: Report of 3 cases. Zhonghua Kou Qiang Ke Za Zhi 1982; 17: 250.

99 Lalikos JF, Sotereanos GC, Nawrocki JS, Tzakis AG. Isolated mandibular metastasis of hepatocellular carcinoma. J Oral Maxillofac Surg 1992; 50: 754-759

100 Levy B, Smith WK. A jaw metastasis from the colon. Oral Surg Oral Med Oral Pathol 1974; 38: 769-772.

101 Li ZL, Chen XL, Wang X. Metastatic tumors to oral and maxillofacial region: report of 2 cases. Stomatology 2005; 25: 18 .

102 Liao HP, Reng SM. Thyroid carcinoma metastatic to the left mandible. Report of a case. Qinghai Yi Yao Za Zhi 1995; 25: 58.

103 Liu HW, Feng YY, Li NY, et al. Metastatic hepatic carcinoma to mandible: report of two cases and review of literature. Acta Acad Med Qingdao Uni 2008; 44: 64-66.

104 Liu SK, Yang W, Dong YY. Choriocarcinoma metastatic to the maxillary alveolar bone: a case report. Xian Dai Kou Qiang Yi Xue Za Zhi 1995; 9: 117.

105 Liu YR, Liu Z, Zhu EX. Metastatic tumors to oral and maxillofacial region. Shanghai Di Er Yi Xue Yuan Xue Bao 1983; 3: 7

$106 \mathrm{Lu}$ AP, Li JM, Shen QB. One case of mandibular metastasis from lung. J Oral Sci Res 2007; 23: 46.

$107 \mathrm{Lu} \mathrm{SY,} \mathrm{Chen} \mathrm{L.} \mathrm{Mandible} \mathrm{metastasis} \mathrm{as} \mathrm{the} \mathrm{initial}$ manifestation of breast carcinoma - report of a case. Zhonghua Ya Yi Xue Hui Za Zhi 1991; 10: 98.

$108 \mathrm{Lv}$ XH. Thyroid carcinoma metastatic to the mandible. report of a case. Jilin Yi Xue 1992; 13:374.

109 Ma FL, Ding HX. Metastatic carcinoma of the mandible: a casereport. Kou Qiang Yi Xue 1987; 7: 64.

110 Ma J, Pang CB, Chen WL, Huang HZ. Rectal carcinoma metastatic to the mandibular condyle: a case report. Kou Qiang He Mian Wai Ke Za Zhi 2003; 13: 255.

111 MacAfee KA 2nd, Quinn PD, Abaza NA. Adenocarcinoma of the colon metastatic to the temporomandibular joint: a case report. J Oral Maxillofac Surg 1993; 51: 793-797.

112 MacGregor AJ, Lewis DA. Metastasis of carcinoma of the lung by implantation in tooth sockets. Br J Oral Surg 1972; 9: 195-199.

113 Marinella MA. Metastatic large cell lung cancer presenting with numb chin syndrome. Respir Med 1997; 91: 235-236.

114 Marker P, Clausen PP. Metastases to the mouth and jaws from hepatocellular carcinomas. A case report. Int J Oral Maxillofac Surg 1991; 20: 371-374.

115 Markitziu A, Fisher D, Marmary Y. Thyroid papillary carcinoma presenting as jaw and parotid gland metastases. Int J Oral Maxillofac Surg 1986; 15: 648-653.

116 Mason AC, Azari KK, Farkas LM, Duvvuri U, Myers EN. Metastatic adenocarcinoma of the colon presenting as a mass in the mandible. Head Neck 2005; 27: 729-732.

117 Maxymiw WG, Wood RE. Metastatic endometrial carcinoma to the mandible: a case report. J Oral Maxillofac Surg 1991; 49: $78-80$.

118 McCarty MJ, Vukelja SJ. Atypical medullary carcinoma of the breast metastatic to the oral cavity. Am J Otolaryngol 1994; 15: 289-291.

119 McDaniel RK, Luna MA, Stimson PG. Metastatic tumors in the Jaws. Oral Surg 1971; 31: 380-386.

120 Mesa ML. Metastatic prostate carcinoma to the mandible: report of case. J Oral Surg 1977; 35: 133-135.

121 Miles BA, Schwartz-Dabney C, Sinn DP, Kessler HP. Bilateral metastatic breast adenocarcinoma within the temporomandibular joint: a case report. J Oral Maxillofac Surg 2006; 64: 712-718.

122 Mizukawa JH, Dolwick MF, Johnson RP, Miller RI. Metastatic breast adenocarcinoma of the mandibular condyle: report of case. J Oral Surg 1980; 38: 448-451.

123 Morris PR, Prstojevich SJ, Hedayati P. Male breast Cancer with maxillofacial metastasis: case report. J Oral Maxillofac Surg 2001; 59: 578-580.

124 Mucitelli DR, Zuna RE, Archard HO. Hepatocellular carcinoma presenting as an oral cavity lesion. Oral Surg Oral Med Oral Pathol 1988; 66: 701-705.

125 Myall RW, Morton TH, Worthington P. Melanoma metastatic to the mandible. Report of a case. Int J Oral Surg 1983; 12: 56-59.

126 Myers WL. Metastatic nephroblastoma of the mandible. Oral Surg Oral Med Oral Pathol 1967; 23: 375-378.

127 Nakamura T, Ishimaru J, Mizui T, et al. Osteosarcoma metastatic to the mandible: a case report. Oral Surg Oral Med Oral Pathol Oral Radiol Endod 2001; 91: 452-454.

128 Neville BW, Damm DD, Allen CM, Bouqout JE. Oral maxillofacial pathology. Philadelphia: WB Saunders Co., 1995: 486-489.

129 Newland JR, McClendon JL, Lynch DP. Metastatic neuroblastoma of the jaws. J Oral Maxillofac Surg 1985; 43: 549-553.

130 Nishimura Y, Yakata H, Kawasaki T, Nakajima T. Metastatic tumours of the mouth and jaws: a review of the 
Japanese literature. J Maxillofac Surg 1982; 10: 253-258.

131 Nitzan DW, Livni N, Marmary Y, et al. The use of monoclonal anti-CEA antibody immunohistochemistry in detecting the origin of oral cavity metastasis. Int J Oral Maxillofac Surg 1990; 19: 162-164.

132 Ogunsalu C, Smith NJ. Metastatic neuroblastoma of the mandible mimicking osteogenic sarcoma radiologically. Case report. Aust Dent J 1999; 44: 207-210.

133 Ogutcen-Toller M, Metin M, Yildiz L. Metastatic breast carcinoma mimicking periodontal disease on radiographs. $J$ Clin Periodontol 2002; 29: 269-271.

134 Ohba T, Katayama H, Nakagawa E, Takeda N. Mandibular metastasis of osteogenic sarcoma. Report of a case. Oral Surg Oral Med Oral Pathol 1975; 39: 821-825.

135 Okada H, Kamino Y, Shimo M, et al. Metastatic hepatocellular carcinoma of the maxillary sinus: a rare autopsy case without lung metastasis and a review. Int J Oral Maxillofac Surg 2003; 32: 97-100.

136 Ord RA, Malins T, Ward-Booth PR. Vascular metastatic renal carcinoma of the maxilla. Report of two cases. Int $J$ Oral Maxillofac Surg 1990; 19: 106-109.

137 Osguthorpe JD, Bratton JR. Occult thyroid carcinoma appearing as a single mandibular metastasis. Otolaryngol Head Neck Surg 1982; 90: 674-675.

138 Ostrosky A, Mareso EA, Klurfan FJ, Gonzalez MJ. Mandibular metastasis of follicular thyroid carcinoma. Case report. Med Oral 2003; 8: 224-227.

139 Ou-Yang KX, Chen WL, Huang ZQ, Li JS, Zhang SB. Renal clear cell car cinoma with mandibular metastasis: a case report and literature review. Chin J Oral Maxillofac Surg 2008; 6: 68-70.

140 Patton LL, Brahim JS, Baker AR. Metastatic malignant melanoma of the oral cavity: a retrospective study. Oral Surg Oral Med Oral Pathol 1994; 78: 51-56.

141 Peacock TR, Fleet JD. Condylar metastasis from a bronchogenic carcinoma. Br J Oral Surg 1982; 20: 39-44.

142 Plath T, Marks C. Pathologic fracture of the mandible caused by intraosseous metastasis of oesophageal squamous cell carcinoma: a case report. Int J Oral Maxillofac Surg 1996; 25: 282-284.

143 Pritchyk KM, Schiff BA, Newkirk KA, Krowiak E, Deeb ZE. Metastatic renal cell carcinoma to the head and neck. Laryngoscope 2002; 112: 1598-1602.

144 Quinn JH, Kreller JS, Carr RF. Metastatic renal cell carcinoma to the mandible: report of case. J Oral Surg 1981; 39: $130-133$.

145 Rachapalli V, Blanco-Guzman M, Jones GM, Oriolowo A. Interesting case: metastatic adrenal adenocarcinoma of the mandible. Br J Oral Maxillofac Surg 2006; 44: 239.

146 Ramanathan K, Eravelly J, Ken TP. Metastatic choriocarcinoma involving the maxilla. Report of a case. Oral Surg Oral Med Oral Pathol 1968; 26: 688-693.
147 Redleaf MI, Robinson RA. Pathologic quiz case 1. Renal cell carcinoma metastatic to the mandible. Arch Otolaryngol Head Neck Surg 1994, 120: 770-772.

148 Ripp GA, Wendth AJ Jr, Vitale P. Metastatic thyroid carcinoma of the mandible mimicking an arteriovenous malformation. J Oral Surg 1977; 35: 743-745.

149 Rocha WC, Curado MP, Vencio EF, Caixeta WB. Endometrial carcinoma metastatic to the mandible: a case report. J Oral Maxillofac Surg 2000; 58: 914-916.

150 Roser SM, Nicholas TR, Hirose FM. Metastatic chondrosarcoma to the maxilla: review of the literature and report of case. J Oral Surg 1976; 34: 1012-1015.

151 Rusthoven JJ, Fine S, Thomas G. Adenocarcinoma of the rectum metastatic to the oral cavity. Two cases and a review of the literature. Cancer 1984; 54: 1110-1112.

152 Salman NI, Langel I. Metastatic tumors of the oral cavity. Oral Surg Oral Med Oral Pathol 1954; 7: 1141-1149.

153 Samit AM, Falk HJ, Ohanian M, Leban SG, Mashberg A. Malignant melanoma metastatic to the mandible. J Oral Surg 1978; 36: 816-821.

154 Sanchez AG, Garcia PA, de la Mata Pages R, Montalvo Moreno JJ. Tumors metastatic to the mandible: analysis of nine cases and review of the literature. J Oral Maxillofac Surg 1990; 48: 246-251.

155 Sanchez-Jimenez J, Acebal-Blanco F, Arevalo-Arevalo RE, Molina-Martinez M. Metastatic tumours in upper maxillary bone of esophageal adenocarcinoma. A case report. Med Oral Patol Oral Cir Bucal 2005; 10: 252-257.

156 Sastre J, Naval L, Munoz M, Gamallo C, Diaz FJ. Metastatic renal cell carcinoma to the mandible. Otolaryngol Head Neck Surg 2005; 132: 663-664.

157 Schwartz ML, Baredes S, Mignogna FV. Metastatic disease to the mandible. Laryngoscope 1988; 98: 270-273.

158 Scott A, Raine M, Stansbie JM. Ethmoid metastasis of endometrial carcinoma causing mucocoele of maxillary antrum. J Laryngol Otol 1998; 112: 283-285.

159 Selden HS, Manhoff DT, Hatges NA, Michel RC. Metastatic carcinoma to the mandible that mimicked pulpal/periodontal disease. J Endod 1998; 24: 267-270.

160 Sengun D, Tuncer I, Ertem N. Metastatic hemangioendotheliosarcoma of the mandible: report of case. $\mathrm{J}$ Oral Maxillofac Surg 1986; 44: 806-810.

161 Shapiro R, Reichman L, Getzoff C, Weiss A. Osteosarcoma of breast metastasizing to the oral cavity. Oral Surg Oral Med Oral Pathol 1967; 23: 58-61.

162 Shen WJ, Du XZ, Zhang SL, Gong FQ. Metastatic neoplasms to oral and maxillofacial region. Xian Dai Zhong Liu Yi Xue 1994; 2: 171-174.

163 Shiraishi T, Nakayama T, Fukutome K, Watanabe M, Murata T. Malignant myoepithelioma of the breast metastasizing to the jaw. Virchows Arch 1999; 435: 520-523.

164 Sidhu SS, Parkash H, Chopra P. Renal metastatic carcinoma 
of the mandible. J Dent 1982; 10: 103-106.

165 Singh HB, Singh H, Chakraborty M. Metastatic osteosarcoma of the maxilla. J Laryngol Otol 1978; 92: 619-622.

166 Slee RW, al-Hilli F, Abdul-Wahab AW. Secondary chordoma of the mandible. Br J Oral Maxillofac Surg 1989; 27: 346349.

167 Snyder MB, Cawson RA. Jaw and pulpal metastasis of an adrenal neuroblastoma. Oral Surg Oral Med Oral Pathol 1975; 40: 775-784.

168 Snyder SL, Marks I. Osteogenic sarcoma metastatic to the mandible. Oral Surg Oral Med Oral Pathol 1968; 25: 216.

169 Snyder SR, Merkow LP, White NS. Prostatic carcinoma metastatic to the mandible: report of case. J Oral Surg 1971; 29: 205-207.

170 Sokolosky M Jr, Bouquot JE, Graves RW. Esophageal carcinoma metastatic to the oral cavity. J Oral Maxillofac Surg 1986; 44: 825-827.

171 Song L, Jin HZ, Ye Q. One case of thyroid carcinoma metastatic to bilateral mandible. Jilin Yi Xue Xin Xi 1995; 6: 33.

172 Spott RJ. Metastatic breast carcinoma disguised as periapical disease in the maxilla. Oral Surg Oral Med Oral Pathol 1985; 60: 327-328.

173 Staton JB, Costello TH, Donovan FD, Laster RE. Cystosarcoma phyllodes metastatic to the mandible: report of a rare case and literature review. Ear Nose Throat J 2003, 82: 380-381.

174 Stavropoulos MF, Ord RA. Lobular adenocarcinoma of breast metastatic to the mandibular condyle. Report of a case and review of the literature. Oral Surg Oral Med Oral Pathol 1993; 75: 575-578.

175 Stockdale CR. Metastatic carcinoma of the jaws secondary to primary carcinoma of the breast. Oral Surg Oral Med Oral Pathol 1959; 12: 1095-1101.

176 Straith FE. Metastatic adenocarcinoma of mandible. Report of a case with a confusing history and symptoms. Oral Surg Oral Med Oral Pathol 1967; 24: 1-5.

177 Stypulkowska J, Bartkowski S, Pana's M, Zaleska M. Metastatic tumors to the jaws and oral cavity. J Oral Surg 1979; 37: 805-808.

178 Svirsky JA, Epstein RA, Dent CD, Avillion G. Small cell carcinoma of the lung metastatic to the wall of a radicular cyst. J Endod 1994; 20: 512-514.

179 Takinami S, Yahata H, Kanoshima A, et al. Hepatocellular carcinoma metastatic to the mandible. Oral Surg Oral Med Oral Pathol Oral Radiol Endod 1995; 79: 649-654.

180 Tenzer JA, Rypins RD, Jakowatz JG. Malignant cystosarcoma phyllodes metastatic to the maxilla. J Oral Maxillofac Surg 1988; 46: 80-82.

181 Terakado N, Shintani S, Nakashiro K, Hamakawa H. Malignant pleural mesothelioma metastasis to the mandible. Int J Oral Maxillofac Surg 2004; 33: 798-800.
182 Thatcher SL, Dye CG, Grau MJ, Neale HW. Carcinoma of the prostate metastatic to the mandibular condyle mimicking a parotid tumor. J Oral Maxillofac Surg 1986; 44: 394-397.

183 Tideman H, Arvier JF, Bosanquet AG, Wilson DF. Esophageal adenocarcinoma metastatic to the maxilla. Oral Surg Oral Med Oral Pathol 1986; 62: 564-568.

184 Treggiden R. Mandibular metastasis from carcinoma of the bladder. J Oral Surg 1976; 34: 1016-1018.

185 van der Kwast WA, van der Waal I. Jaw metastases. Oral Surg Oral Med Oral Pathol 1974; 37: 850-857.

186 Vigneul JC, Nouel O, Klap P, Al Helali M. Metastatic hepatocellular carcinoma of the mandible. J Oral Maxillofac Surg 1982; 40: 745-749.

187 Vrebos JE, Masson JK, Harrison EG Jr. Metastatic carcinoma of the mandible with primary tumor in the lung. Am J Surg 1961; 102: 52-57.

188 Vural E, Hanna E. Metastatic follicular thyroid carcinoma to the mandible: a case report and review of the literature. $\mathrm{Am}$ J Otolaryngol 1998; 19: 198-202.

189 Wang CL, Yacobi R, Pharoah M, Thorner P. Ewing's sarcoma: metastatic tumor to the jaw. Oral Surg Oral Med Oral Pathol 1991; 71: 597-602.

190 Wang HJ, Chen WL. Metastatic tumors to the mandible: report of 4 cases. Guangdong Ya Bing Fang Zhi 2002; 10: 60.

191 Wang SR, Wang WR, Wei GY. Lung Cancer metastatic to the mandible. report of a case. Lin Chuang Kou Qiang Yi Xue Za Zhi 1993; 9: 128.

192 Wang XY. Metastatic tumors to the mandible: report of 2 cases. Kou Qiang He Mian Wai Ke Za Zhi 1995; 5: 54.

193 Watts PG. Secondary cholangiocarcinoma in the mandible. Br Dent J 1979; 146: 385-386.

194 Webster K. Adenocarcinoma metastatic to the mandibular condyle. J Craniomaxillofac Surg 1988; 16: 230-232.

195 Willard CC, Weber CR, Buche W. Metastatic esophageal adenocarcinoma involving the maxilla. J Oral Maxillofac Surg 2002; 60: 1496-1499.

196 Wolujewicz MA. Condylar metastasis from a carcinoma of the prostate gland. Br J Oral Surg 1980;18: 175-182.

197 Woolf MA, Crumley RL. Chordoma. Report of a rare mandibular metastasis. Otolaryngol Head Neck Surg 1984; 92: $237-240$.

$198 \mathrm{Wu} \mathrm{HB}$, Wang $\mathrm{H}$. Metastatic tumor to the mandible presenting toothache and trismus. Hua Xi Kou Qiang Yi Xue Za Zhi 1998; 16: 190.

199 Wu YT, Zhang ZY, Yu SF. Metastatic carcinoma to the oral tissues and jaws: a study of 25 cases. Zhonghua Kou Qiang Yi Xue Za Zhi 1990; 25: 258.

$200 \mathrm{Xu} \mathrm{JB}$, Chen F, Hou DF, Li GZ. One case of mandibular metastasis from liver. Chin Arch Otolaryngol Head Neck Surg 2005; 12: 748.

201 Xue CH. Metastasis to oral region (report of four cases). 
Tianjin Med J 2000; 28: 118.

202 Yacabucci JE, Mainous EG, Kramer HS. Hepatocellular carcinoma, diagnosed following metastasis to the mandible. Report of a case. Oral Surg Oral Med Oral Pathol 1972; 33: 888-893.

203 Yang GY, Zhao RR. Lung Cancer metastatic to the mandible: a case report. Lin Chuang Kou Qiang Yi Xue Za Zhi 1995; 11: 143.

204 Yang JM, Wang QQ. Metastatic hepatocellular carcinoma of the right mandible misdiagnosed as a primary parotid tumor: a case report. Zhongguo Zhong Liu Lin Chuang 1994; 21: 624 .

205 Ye WX, Zieper MB, Kelley EO. Breast carcinomas metastatic to the jaws: report of five cases. J Oral Maxillofac Surg 1999; 9: 342-343.

206 Yoshimura Y, Inoue Y, Mihara Y, Miura H. Metastatic malignant cystosarcoma phyllodes: report of a case presenting with an oral tumour and review of the literature. $J$ Craniomaxillofac Surg 1991; 19: 227-231.

207 Yoshimura Y, Matsuda S, Naitoh S. Hepatocellular carcinoma metastatic to the mandibular ramus and condyle: report of a case and review of the literature. J Oral Maxillofac Surg 1997; 55: 297-306.

208 Zachariades N, Koumoura F, Sklavounou-Andrikopoulou A, Papadakis D. Small cell carcinoma metastatic to the mandible. Report of a case. Int J Oral Maxillofac Surg 2004; 33 : 307-309.

209 Zachariades N, Papanicolaou S. Breast cancer metastatic to the mandible. J Oral Maxillofac Surg 1982; 40: 813-818.

210 Zachariades N. Neoplasms metastatic to the mouth, jaws and surrounding tissues. J Craniomaxillofac Surg 1989; 17: 283-290.

211 Zhang HC, Huang DC, Sun ZS. Metastatic tumors to the mandible: a case report. Zhonghua Kou Qiang Yi Xue Za Zhi 1998; 23: 114.

212 Zhang XH, Yao F, Liu SF. Breast Cancer metastatic to the maxilla: a case report. Lin Chuang Kou Qiang Yi Xue Za Zhi
1995; 11: 146.

213 Zhao XZ, Chen YM. Thyroid carcinoma metastatic to the mandible and thoracic vertebrae: a case report. Kou Qiang He Mian Wai Ke Za Zhi 1998; 8: 292.

214 Zhao YP, Gao Y, Ma XC. Thyroid carcinomas metastatic to the mandibular condyle: report of 2 cases. Zhonghua Kou Qiang Yi Xue Za Zhi 2001; 36: 93.

215 Zheng JS, Sun T. Renal clear cell carcinoma metastatic to the mandible. Tianjing Yi Yao 1996; 24: 679.

216 Zhou XL, Song M. Adrenal cortical carcinoma metastatic to the mandible. Report of a case. Kou Qiang He Mian Wai Ke Za Zhi 2003; 13: 184.

217 Fidler IJ, Wilmanns C, Staroselsky A, et al. Modulation of tumor cell response to chemotherapy by the organ environment. Cancer Metast Rev 1994; 13: 209-222.

218 Hart IR, Fidler IJ. Role of organ selectivity in the determination of metastatic patterns of the B16 melanoma. Cancer Res 1980; 40: 2281-2287.

219 Fidler IJ. The pathogenesis of cancer metastasis: the "seed and soil" hypothesis revisited. Nature reviews. Cancer 2003; 3: $453-458$.

220 Fidler IJ, Poste G. The "seed and soil" hypothesis revisited. Lancet Onco 2008; 9: 808.

221 Fidler IJ. Modulation of the organ microenvironment for the treatment of cancer metastasis (editorial). J Natl Cancer Inst 1995; 87: 1588-1592.

222 Mendoza M, Khanna C. Revisiting the seed and soil in cancer metastasis. Int J Biochem Cell Biol 2009; 41: 1452 1462.

223 van der Pluijm G, Que I, Sijmons B, et al. Interference with the microenvironmental support impairs the de novo formation of bone metastases in vivo. Cancer Res 2005; 65: 7682-7690.

224 Coleman RE. Adjuvant bisphosphonates in breast cancer: are we witnessing the emergence of a new therapeutic strategy? Eur J Cancer 2009; 45: 1909-1915. 